Journal of Aafiyah Health Research (JAHR)

P-ISSN: 2722-4929 \& E-ISSN: 2722-4945

Published by Postgraduate Program in Public health, Muslim University of Indonesia

Original Research

Open Access

\title{
ANALISIS SPASIAL RISK ASSESMENT DAN IDENTIFIKASI MIKROPLASTIK DAN KEBERADAAN PSEUDOMONAS SEBAGAI BIOREMIDIASI DI PERAIRAN KOTA MAKASSAR
}

\author{
"Muhammad Suharsono", Muhammad Ikhtiar', Alfina Baharuddin ${ }^{2}$ \\ ${ }^{1}$ Balai Prasarana Pemukiman Wilayah Sulawesi Selatan, Kementrian Pekerjaan Umum \\ dan Perumahan Rakyat \\ ${ }^{2}$ Departement Kesehatan Lingkungan, Fakultas Kesehatan Masyarakat, Universitas \\ Muslim Indonesia, Makassar, Indonesia.
}

*Email: suharsonoanno@gmail.com

\begin{abstract}
ABSTRAK
Latar Belakang: Mikroplastik (MPs) memberikan dampak kontaminasi dan cemaran yang serius terhadap kehidupan perairan laut yang mempengaruhi rantai-rantai makanan perairan tersebut. Mikroplastik dikonsumsi oleh organisme yang berukuran mulai dari ukuran besar sampai ukuran terkecil di habitat atau ekosistem tersebut. Mikroplastik ini mengancam ekosistem laut dan kesehatan manusia. Penelitian ini bertujuan untuk mengidentifikasi dan memetakan mikroplastik dan mengindentifikasi keberadaan bakteri Pseudomonas sebagai mikroba pengurai di perairan Kota Makassar. Metode: Penelitian ini dilaksanakan pada bulan Januari-Februari 2021, di Pelabuhan Paotere dan Tanjung Bayam. Hasil: Hasil penelitian ini ditemukan kelimpahan mikroplastik pada Pelabuhan

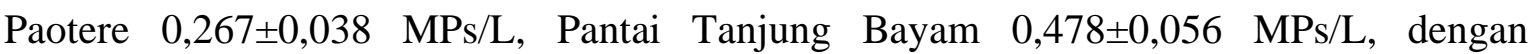
karakteristik bentuk dan ukuran yang sama dan secara umum memiliki warna mikroplastik yang berbeda. Kelimpahan mikroplastik yang tinggi pada sungai menunjukkan bahwa mikroplastik dari sumber daratan. Keberadaan Pseudomonas di perairan kota makassar juga berperan dalam degradasi plastik menjadi mikroplastik. Kesimpulan: Hasil ini menunjukkan bahwa perairan di Kota Makassar telah tercemar oleh partikel mikroplastik. Saran dari penelitian yaitu kepada pemerintah untuk mengatur pengelolaan sampah plastik, dengan keterlibatan penegak hukum dan stake holder terkait agar masyarakat tidak membuang sampah plastik pada aliran sungai, drainase maupun laut.
\end{abstract}

Kata Kunci: Kelimpahan Mikroplastik, Pseudomonas, Perairan Kota Makassar 


\begin{abstract}
Microplastics (MPs) have a serious contamination and contamination impact on marine aquatic life that affects these aquatic food chains. Microplastics are consumed by organisms ranging in size from large to smallest in the habitat or ecosystem. These microplastics threaten marine ecosystems and human health. This research berdestinationto identify and map microplastics and identify the presence of bacteria Pseudomonas as decomposing microbes in Makassar City waters. This research was conducted in JanuaryFebruary 2021, at the Paotere Harbor and Tanjung Bayam. The results of this study found an abundance of microplastics in the Paotere Harbor $0.267 \pm 0.038$ MPs / L, Tanjung Bayam Beach $0.478 \pm 0.056$ MPs / L, with the same shape and size characteristics and generally have a microplastic color different. The high abundance of microplastics in the river indicates that the microplastics are from land sources. The existence of Pseudomonas in the waters of the city of Makassar also plays a role in the degradation of plastics into microplastics. These results indicate that the waters in Makassar City have been polluted by microplastic particles. Suggestions from research are togovernment to regulate plastic waste management, with the involvement of law enforcers and related stakeholders so that people do not throw plastic waste into rivers, drainage and sea.
\end{abstract}

Keywords: abundance of microplastics, the presence of Pseudomonas in Makassar City waters.

\section{PENDAHULUAN}

Polusi plastik di lingkungan saat ini telah menjadi permasalahan yang serius. Produksi plastik dunia mengalami peningkatan setiap tahunnya dan mencapai 322 juta ton pada tahun 2015. Diperkirakan bahwa jumlah produksi ini akan meningkat 100 kali lipat pada tahun 2050 mendatang. Plastik sendiri ternyata menyumbang $10 \%$ dari total sampah yang dihasilkan oleh manusia (World Bank, 2015). Sebagian besar plastik yang dibuang tidak mengalami daur ulang dan dibuang ke lingkungan dan berakhir di laut, yang selanjutnya menjadi sumber polusi di lautan. (1)

Di Indonesia produksi plastik juga mengalami kenaikan pada pada tahun 2018 sebesar $6,92 \%$ dari tahun 2017 yang tercatat $2,47 \%$. Total produksi sektor plastik di tahun 2018 mencapai 7,23 ton. Diperkirakan jumlah produksi plastik akan terus meningkat hingga mencapai 100 kali lipat pada tahun 2050 mendatang. Sampah plastik di lautan Indonesia diperkirakan mencapai 187,2 juta ton per tahun. (2)

Sumber pencemaran lingkungan berasal dari kegiatan industri, perikanan, pelabuhan, perhotelan, pariwisata bahari 
dan rumah tangga. (3) Berdasarkan data dari Sistem Informasi Pengelolaan Sampah Nasional (SIPSN) kementerian Lingkungan Hidup dan Kehutanan, produksi sampah di Kota Makassar tahun 2018 yaitu 1.425 ton/hari timbulan sampah dengan pembagian 1.000 ton/hari yang ditimbun di TPA dan 425 ton/hari yang tidak dikelola. Dengan persentase timbulan sampah rumah tangga $62,99 \%$, kantor $8,49 \%$, pasar tradisional $2,98 \%$, pusat perniagaan 13,37\%, fasilitas publik 1,13\%, kawasan $0,90 \%$, lainnya $10,14 \%$.

Dampak dari pencemaran plastik salah satunya yaitu banyak hewan laut yang mengkonsumsi plastik tersebut sehingga mengancam keberlansungannya. Belakangan ini telah diketahui bahwa sampah plastik yang mengendap di lautan seiring dengan waktu dapat terdegradasi menjadi partikel yang lebih kecil. Sampah plastik yang terdegradasi menjadi potongan-potongan plastik kecil dikenal dengan nama mikroplastik. (4)

Mikroplastik adalah partikel plastik yang memiliki diameter $<5 \mathrm{~mm}$. Ukuran mikroplastik yang kecil memungkinkan biota untuk mencernanya, baik secara langsung maupun tidak langsung. Sumber mikroplastik ada dua yaitu sumber primer dan sumber sekunder. Mikroplastik primer diproduksi sebagai partikulat seperti pelet untuk bahan baku industri. Mikroplastik sekunder berasal dari plastik ukuran besar yang terdegradasi dan akibatnya terfragmentasi menjadi partikel mikroplastik. (5)

Graha Menurut Nugraha (2020), kandungan mikroplastik dalam tubuh manusia pada jumlah tertentu dapat meningkatkan resiko penyakit kanker. Berdasarkan kondisi tersebut sehingga diperlukan solusi untuk mengurangi hingga menghilangkan kandungan mikroplastik. Salah satu strategi dan pendekatan yang menarik untuk mengendalikan pencemaran mikroplastik dapat dilakukan adalah dengan pendekatan teknologi bioremediasi. (6)

Berdasarkan hasil penelitian oleh Nugraha (2020), yaitu dengan adanya mikroorganisme indigenous sebagai pengurai plastik yang ditemukan, memiliki potensi bioteknologi yang besar untuk dapat membantu proses bioremediasi alami dalam mengurangi pencemaran mikroplastik pada ekosistem perairan.Berdasarkan hal tersebut, maka peneliti tertarik meneliti mengenai "Analisis Spasial Risk Assesment Dan Identifikasi Mikroplastik 
Dan Keberadaan Pseudomonas Sebagai Bioremidiasi Di Perairan Kota Makassar".

\section{METODE}

Penelitian ini merupakan observasional deskriptif untuk memeriksa,mengidentifikasi dan memetakan kandungan mikroplastik dan Pseudomonas sp pada perairan Kota Makassar dengan titik pengambilan sampel yang berbeda, dengan penilaian Risk Assessment. Rancangan penelitian ini menggunakan pendekatan Sistem Informasi Geografis (SIG). Pengambilan data menggunakan metode eksplorasi yaitu pengambilan sampel dilakukan secara langsung.

Penelitian ini dilaksanakan di 2 stasiun Perairan Kota Makassar yaitu Pelabuhan Paotere dan Pantai Tanjung Bayam dengan tiap stasiun mengambil sampel di 3 titik yang berbeda selama kurang lebih 1 bulan pada bulan Jañanuari
- Februari tahun 2021. Selanjutnya dilakukan uji lanjutan yakni diidentifikasi secara visual menggunakan mikroskop stereomik (Euromex SB1902) di Laboratorium Ekotoksikologi Laut Fakultas Ilmu Kelautan dan Perikanan Universitas Hasanuddin Makassar. Selanjutnya dilakukan Isolasi dan Identifikasi Bakteri Mikroplastik, Identifikasi bakteri menggunakan instrumen otomatis VITEX-2 Compact yang bekerja berdasarkan penentuan MIC (Minimum Inhibitory Concentration) dan Pengujian Bakteri Pendegradasi di Laboratorium Fakultas MIPA UNHAS.

\section{HASIL DAN PEMBAHASAN IDENTIFIKASI}

MIKROPLASTIK. Hasil pengukuran kelimpahan mikroplastik pada perairan Pelabuhan Paotere dan Pantai Tanjung Bayam ${ }_{\llcorner)}$dapat dilihat pada gambar 1 berikut.

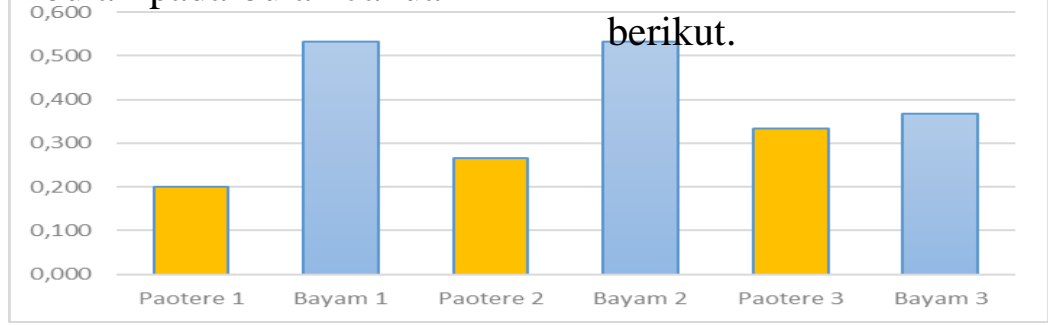

Gambar.1 Kelimpahan Mikroplastik

Berdasarkan gambar 1, ditemukan pada sampel di kawasan Kelimpahan jumlah mikroplastik yang pelabuhan paotere di Titik 1 0,200 
MPs/L, Titik 2 0,267 MPs/L, Titik 3 0,333 MPs/L dengan kelimpahan ratarata $0,267 \pm 0,038 \mathrm{MPs} / \mathrm{L}$. Sampel di kawasan pantai tanjung bayam di Titik 1 sebanyak 0,533 MPs/L, Titik 2 0,533 MPs/L, Titik 3 0,367 MPs/L. dengan kelimpahan rata-rata $0,478 \pm 0,056$ MPs/L.

Bentuk mikroplastik pada perairan Pelabuhan Paotere dan Pantai Tanjung Bayam dapat dilihat pada gambar 2 berikut.

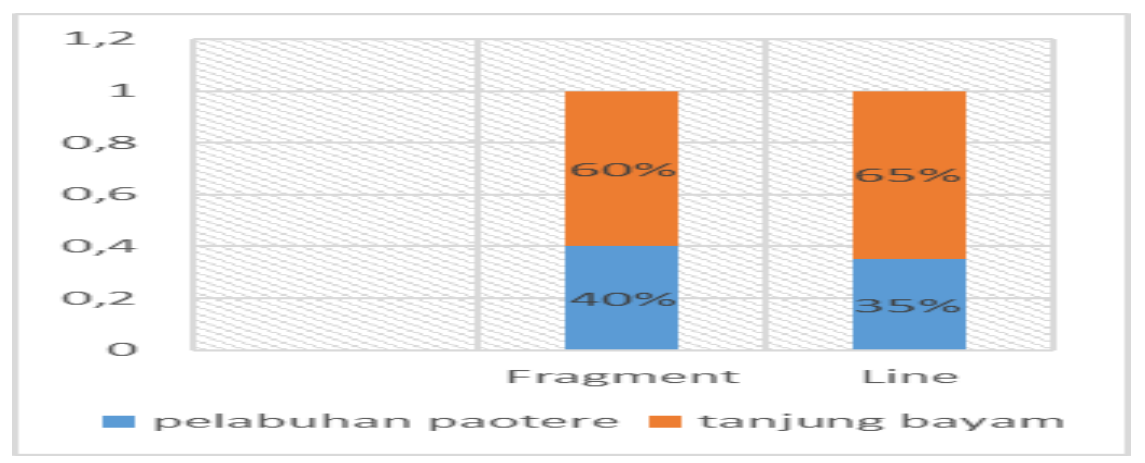

Gambar 2. Bentuk Mikroplastik

Berdasarkan gambar 2, proporsi jumlah mikroplastik berdasarkan bentuknya di Pelabuhan Paotere yaitu Fragmen $40 \%$ dan Line atau Fiber 35\%. Sedangkan proporsi jumlah mikroplastik berdasarkan bentuknya di Pantai
Tanjung Bayam yaitu Fragmen 60\% dan Line atau Fiber 65\%.

Warna mikroplastik pada perairan Pelabuhan Paotere dan Pantai Tanjung Bayam dapat dilihat pada gambar 3 berikut.

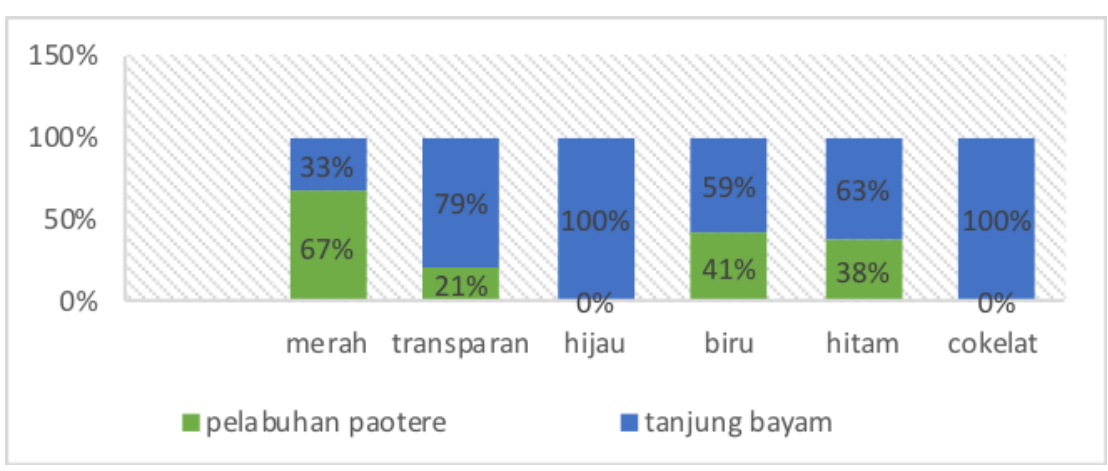

Gambar 3. Warna Mikroplastik

Berdasarkan gambar 3, proporsi jumlah mikroplastik berdasarkan warnanya di Pelabuhan Paotere dan Tanjung bayam yaitu merah $67 \%$ dan $33 \%$, warna transparan $21 \%$ dan $79 \%$, warna hijau hanya ditemukan di Pantai Tanjung Bayam, warna biru $41 \%$ dan $59 \%$, warna hitam $38 \%$ dan $63 \%$ dan warna cokelat hanya ditemukan pada Pantai Tanjung Bayam. 
Ukuran mikroplastik pada Tanjung Bayam dapat dilihat pada perairan Pelabuhan Paotere dan Pantai gambar 4 berikut.

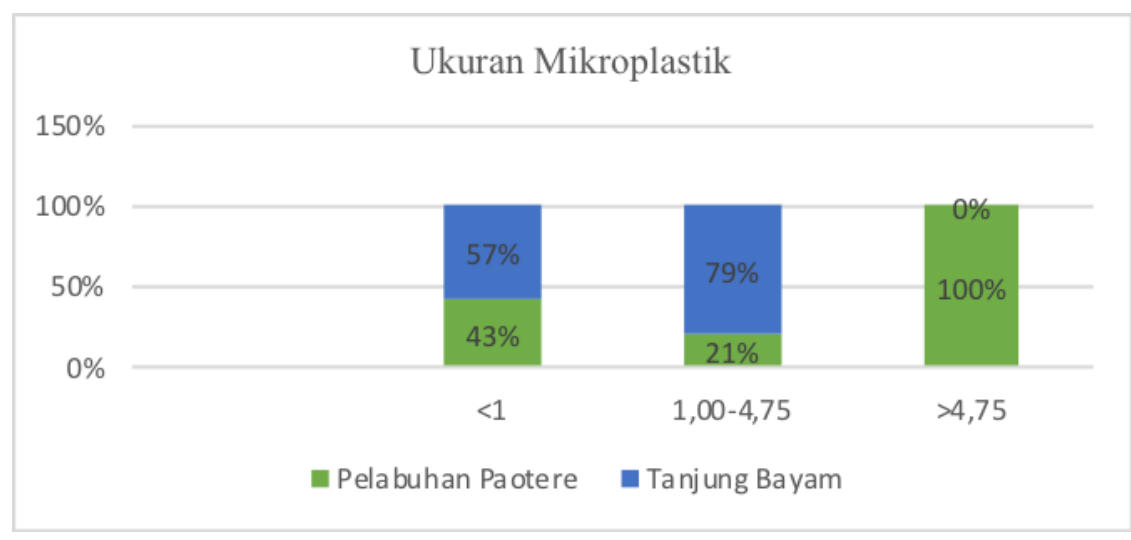

Gambar 4. Ukuran Mikroplastik

Berdasarkan gambar 4, proporsi jumlah mikroplastik berdasarkan ukurannya, di Pelabuhan Paotere ukuran mikroplastik <1 mm sebanyak 43\% dan berukuran 1,00-4,75 sebanyak $21 \%$ dan ditemukan mikroplastik berukuran $<4,75$. Sedangkan di perairan Pantai Tanjung Bayam ditemukan ukuran mikroplastik <1 mm sebanyak 57\% dan berukuran 1,00-4,75 sebanyak $79 \%$ dan tidak ditemukan mikroplastik berukuran $<4,75$.

\section{KEBERADAAN}

PSEUDOMONAS

SEBAGAI

BIOREMIDIASI. Hasil pengukuran keberadaan Pseudomonas pada perairan Pelabuhan Paotere dan Pantai Tanjung Bayam dapat dilihat pada gambar 5 berikut.
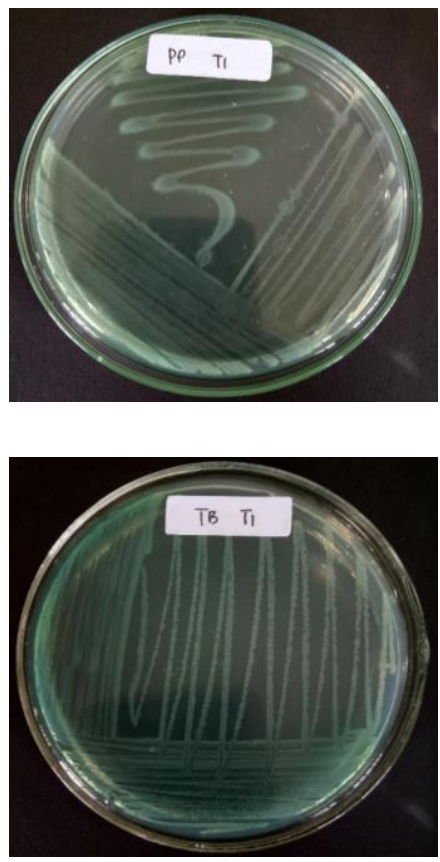

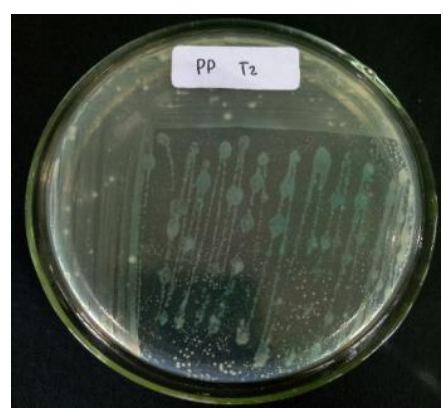

(a) Pelabuhan Paotere

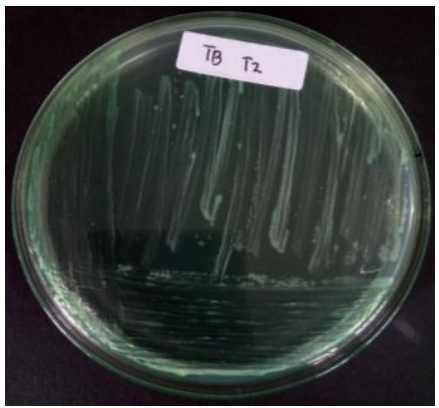

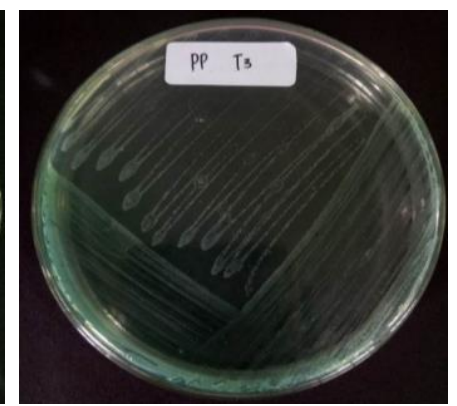

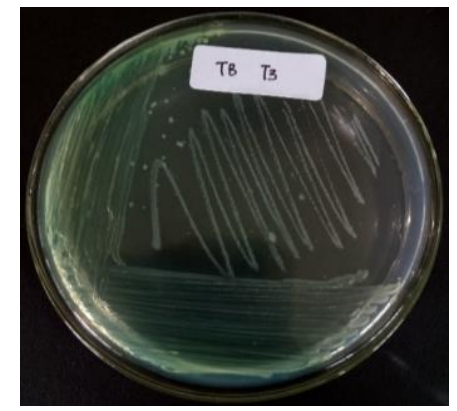


(b) Pantai Tanjung Bayam

Gambar 5. Keberadaan Pseudomonas pada perairan Pelabuhan Paotere dan perairan Pantai Tanjung Bayam

Berdasarkan gambar 5 keberadaan

Pseudomonas di perairan Pelabuhan

Paotere dan perairan Pantai Tanjung
Bayam ditandai adanya pertumbuhan koloni berwarna kehijauan pada media Certrimide Agar (CETA).

DISTRIBUSI SPASIAL MIKROPLASTIK DAN PSEUDOMONAS. Sebaran Mikroplastik dan Pseudomonas dapat dilihat pada gambar 6.
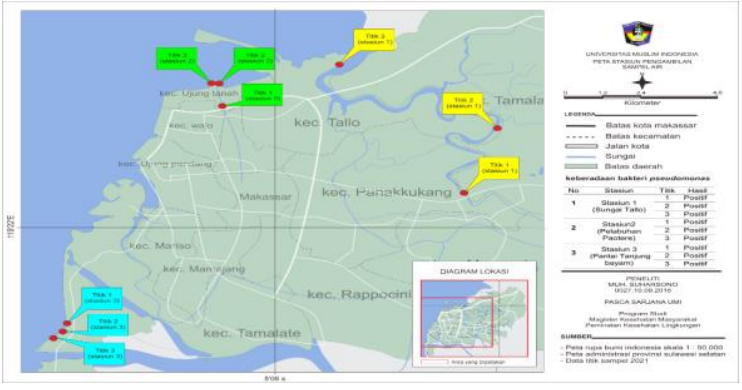

(a) Sebaran Mikroplastik
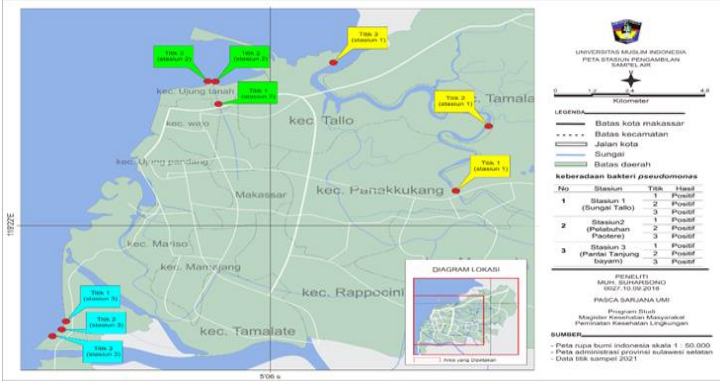

(b) Keberadaan Pseudomonas

Gambar 6. Sebaran Mikroplastik dan keberadaan Pseudomonas pada perairan Kota Makassar

Berdasarkan gambar 6 mikroplastik terdapat pada semua titik pengambilan sampel dan terdapat lebih banyak kelimpahan mikroplastik di Tanjung Bayam dibanding dengan Pelabuhan Paotere. Dan juga di semua perairan Kota Makassar terdapat Pseudomonas.

\section{PEMBAHASAN}

\section{IDENTIFIKASI MIKROPLASTIK.}

Kelimpahan mikroplastik pada Tanjung
Bayam lebih tinggi dibanding dengan perairan Pelabuhan Paotere, Hal ini dikarenakan mikroplastik yang dihasilkan berasal dari berbagai kegiatan manusia mulai perindustrian, pelabuhan, perikanan (budidaya dan penangkapan), kepariwisataan, pemukiman dan dan secara tidak langsung sebagai lahan pembuangan limbah. Kawasan pantai Tanjug Bayam juga terhubung dengan sungai jeneberang yang melintasi Kota 
Makassar dan Kabupaten Gowa sehingga menyebabkan limbah plastik meningkat. Hasil penelitian sebelumya dilakukan oleh Wicaksono (2020) yang menemukan bahwa kandungan mikroplastik di muara Sungai Jeneberang lebih tinggi dibanding dengan bagian lainnya. Selain itu, faktor lingkungan seperti angin dan arah arus juga dapat menentukan distribusi mikroplastik, kegiatan pariwisata dan perikanan memainkan peran penting dalam meningkatkan konsentrasi mikroplastik. (7)

Kelimpahan mikroplastik di Pelabuhan Paotere dikarenakan mikroplastik yang dihasilkan berasal dari berbagai aktivitas penduduk yang sangat beragam berupa aktivitas rumah tangga dan transportasi kapal dan aktifitas perdagangan di pelelangan ikan paotere. Kawasan pelabuhan paotere juga terhubung dengan kanal panampu dan jongaya yang melintasi pusat Kota Makaasar. Hasil penelitian ini sesuai dengan hasil penelitian Rahmadhani (2019) bahwa daerah sekitar pelabuhan atau lalu lintas kapal memiliki keberadaan mikroplastik. (8) Namun kelimpahan mikroplastik di Pelabuhan Paotere masih lebih rendah dibanding dengan perairan Tanjung Bayam, hal ini disebabkan salah satunya jumlah penduduk di sekitaran Pelabuhan Paotere lebih sedikit dibanding dengan jumlah penduduk di kawasan perairan Tanjung Bayam. Pelabuhan Paotere berada pada Kecamatan Ujung Tanah dengan jumlah penduduk 35.534 jiwa atau $2 \%$ dari total jumlah penduduk Kota Makassar dan perairan Tanjung Bayam berada pada Kecamatan Tamalate dengan jumlah penduduk 205.541 jiwa atau $13 \%$ dari total jumlah penduduk Kota Makassar. (BPS, 2020) Selain jumlah kelimpahan mikroplastik keseluruhan yang berbeda, hasil pengukuran kelimpahan bentuk, warna dan ukuran mikroplastik pada Pelabuhan Paotere dan Pantai Tanjung Bayam juga berbeda, hal ini dapat dilihat Berdasarkan gambar 2, Dilihat dari bentuk mikroplastik, keberadaan mikroplastik di Pelabuhan Paotere dan perairan Pantai Tanjung Bayam, di dominasi di Pantai Tanjung Bayam, baik bentuk Line atau fiber dan Fragmen dibanding dengan Pelabuhan Paotere. Meskipun demikian dapat kita lihat bahwa terdapat perbedaan bentuk yang dominan.

Di perairan Pantai Tanjung Bayam yang dominan adalah berbentuk Line atau fiber. Keberadaan mikroplastik berbentuk Line atau garis di Pantai Tanjung Bayam lebih tinggi dibanding 
dengan perairan Pelabuhan Paotere karena perbedaan aktifitas pada kedua lokasi. Tipe line atau fiber atau berbentuk seperti benang banyak ditemukan di perairan Pantai Tanjung Bayam, keberadaan mikroplastik berbentuk fiber/line ini dapat berasal dari proses fragmentasi alat penangkap ikan seperti jaring, senar pancing, atau berasal dari limbah serat pakaian (benang) yang terdapat pada perairan Pantai Tanjung Bayam, juga aktifitas nelayan lainnya. Aktivitas kapal nelayan yang membawa ikan di kawasan Pantai Tanjung Bayam juga menyebabkan kelimpahan mikroplastik berbetuk line atau fiber, yang berasal dari degradasi tali kapal. Penemuan mikroplastik di perairan Indonesia yang dominan ditemukan adalah bentuk line atau fragmen, hal ini seperti yang diungkapkan dalam penelitian Teknik Kelautan (2020) bahwa mayoritas mikroplastik yang ada di Indonesia ratarata baik di perairan tawar, laut, dan dalam tubuh organisme bentuk mikroplastik yang banyak ditemukan adalah fiber, dibandingkan dengan bentuk yang lainnya. (9)

Hal ini sesuai dengan penelitian Ramadhani (2020), bahwa mikroplastik fiber berasal dari degradasi tali kapal yang terurai masuk ke perairan dan terakumulasi dalam tubuh biota maupun air. Sebaliknya, bagian kawasan Pelabuhan Paotere di dominasi bentuk fragmen. Keberadaan partikel fragmen yang berasal dari sampah plastik yang lebih besar seperti yang diungkapkan Wicaksono (2020) bahwa Keberadaan fragmen umumnya berasal dari fragmentasi plastik yang lebih besar. Kelimpahan partikel fragmen yang lebih tinggi dibanding bentuk line di Pelabuhan Paotere juga disebabkan aktifitas warga disekitar yang membuang sampah pada kanal dan juga sampah dari rumah makan di kawasan tersebut Meski begitu tidak diketahui plastik berukuran besar berasal dari jenis apa, karena tidak ada identifikasi polimer.

Warna MPs yang dominan di kedua lokasi tidak jauh berbeda. Pelabuhan Paotere cenderung didominasi oleh warna merah $(25 \%)$ dibanding dengan warna mikroplastik yang lainnya, sedangkan Pantai Tanjung Bayam didominasi warna transparan (37\%) dan juga terdapat mikroplastik berwarna biru, hijau, cokelat dan hitam. Menurut wicaksono (2020) bahwa warna mikroplastik dapat menjadi informasi yang berguna untuk menentukan sumber partikel. Sebuah studi yang dilakukan di Yangtze 
Estuary, China, menemukan bahwa warna MP juga didominasi oleh partikel MP yang berwarna dan transparan. Keberadaan partikel MPs yang transparan dan berwarna sebagian besar berasal dari fragmentasi kemasan plastik bening, pakaian dan tali pancing. Kelimpahan ukuran mikroplastik $\leq 5 \mathrm{~mm}$ di kedua lokasi, menandakan bahwa akumulasi sampah plastik di lokasi tersebut sudah lama dan terdegradasi.

\section{KEBERADAAN}

PSEUDOMONAS berperan dalam penguraian plastik menjadi mikroplastik. Perubahan ukuran sampah plastik terjadi karena proses degradasi yang dapat mengubah polimer plastik diklasifikasikan enam proses degradasi polimer plastik yaitu photooxidative degradation, thermal degradation, ozoneinduced degradation, mechanochemical degradation, catalytic degradation dan biodegradation. (10) Hal ini seperti yang dikemukakan pada penelitian Sriningsih A (2015) bahwa Pseudomonas mampu mendegradasi plastik sebelumnya bakteri Pseudomonas sp. mampu mendegradasi plastik. Berdasarkan hasil penelitian (11) bahwa bakteri Pseudomonas sp. mampu mendegradasi plastik dengan persen penyisihan berkisar antara 2-
19\%. Dengan demikian, bakteri ini mampu menjadi biodegradator pilihan untuk melakukan biodegradasi plastik. Namun waktu yang dibutuhkan Psudomonas dalam mengurai plastik sangat lama. (12)

\section{DISTRIBUSI}

SPASIAL MIKROPLASTIK. Mengindikasikan bahwa perairan kota makassar telah tercemar mikroplastik, meskipun masih dalam jumlah yang sedikit dalam tiap liter pengambilan sampelnya. Perbedaan kelimpahan mikroplastik dipengaruhi oleh aktivitas dan sumber pencemarnya. Kelimpahan mikroplastik lebih tinggi di Tanjung Bayam karena banyaknya aktivitas penangkapan ikan, perindustrian dan aktivitas rumah tangga tersebut, terjadi pembuangan di wilayah pemukiman. Hal ini sesuai dengan yang diungkapkan oleh Wicaksono (2020) bahwa Keberadaan lokasi pemukiman dapat menghasilkan partikel MPs yang lebih tinggi dari kegiatan antropogenik ke perairan sekitarnya. juga menyatakan bahwa pada bagian sungai yang terletak di daerah berpenduduk tinggi akan memiliki partikel MPs yang lebih tinggi di air permukaan, dan sebagian besar peningkatan kelimpahan MPs di air mirip dengan peningkatan polutan berbasis antropogenik lainnya. 
TOKSISITAS

KEBERADAAN MIKROPLASTIK.

Setelah dilakukan analisis mikroplastik pada sampel air dan mengetahui keberadaannya di perairan kota makassar, maka dapat dikatakan bahwa perairan kota makassar telah tercemar oleh plastik. Hal yang perlu diperhatikan mengenai pencemaran plastik ini adalah terkait dampak untuk organisme serta lingkungan laut juga mengenai bahaya mikroplastik jika telah masuk ke dalam rantai makanan. Dalam hasil studinya (13) berpendapat bahwa pencernaan anthropogenic debris oleh organisme laut akan memasuki jaringan makanan dan memiliki pengaruh untuk kesehatan manusia. Proses masuknya mikroplastik ke dalam rantai makanan dimulai dari organisme yang berada pada tingkat terbawah pada rantai makanan. Hal ini juga dijelaskan oleh (13) bahwa faktor utama kontribusi mikroplastik memasuki rantai makanan adalah karena ukurannya yang kecil. Diawali dengan plankton yang dapat menelan mikroplastik secara pasif selama proses feeding. Warna dari mikroplastik juga berpotensi memberi kontribusi terkait dengan kemiripannya dengan makanan organisme laut. Beberapa jenis ikan yang memakan zooplankton dapat memakan mikroplastik karena8kemiripannya dengan mangsa yang memilki warna putih, kecoklatan atau kuning muda.

Mikroplastik dapat menjadi racun bagi organisme dengan cara mentransfer senyawa kimia dari air laut ke organisme melalui pencernaan. Berkaitan dengan sifatnya yang hidrofobik, terhadap senyawa persistent organics pollutants7(POPs) seperti PAH, PCB, dan DDTs yang dapat terserap pada permukaan mikroplastik (14). Ketika ada mikroplastik yang masuk dan terperangkap, maka partikel tersebut dapat tertahan di bagian pencernaan dan dapat berpindah melalui garis epitel pada usus lalu masuk ke dalam jaringan tubuh. Keberadaan partikel mikroplastik pada sistem sirkulasi juga dapat menghambat aliran darah yang akan menyebabkan kerusakan sistem vaskular dan perubahan aktivitas jantung. (15) Mikroplastik dapat menyerap berbagai macam kontaminan termasuk polycyclic aromatic hydrocarbons (PAHs), yang terdistribusi cukup besar di ekosistem air sungai dan laut. Diantara senyawa PAHs, phenanthrene (Phe) adalah salah satu dari PAHs yang kontaminasinya sudah tersebar luas dan telah dibuktikan menyebabkan toksisitas pada ikan dan manusia. (16) 
Hasil penelitian Karami A (2017) menyebutkan bahwa terlepasnya monomer ethylene dari partikel HDPE menyebabkan pembentukan etilen oksida dan etilen glikol yang telah diketahui memiliki efek toksis bagi manusia dan hewan. (17) Sejauh ini belum ada penelitian secara detail tentang bahaya mikropartikel atau mikroplastik. Walaupun dapat diprediksi bahwa mikroplastik dapat berada pada lambung dan akan terjadi reaksi adsorpsi yang didukung dengan luas permukaannya yang besar menyebabkan protein dan glikoprotein akan teradsorpsi ke permukaan partikel. (17) Hal ini dapat berdampak pada sistem imun dan terjadi inflamasi pada bagian pencernaan, dan mengancam kesehatan masyarakat di Kota Makassar.

\section{KESIMPULAN}

Berdasarkan hasil penelitian yang telah dilakukan, maka dapat Ditarik kesimpulan sebagai berikut.

1. Distribusi mikroplastik pada perairan kota makassar menunjukkan bahwa kawasan Pantai Tanjung Bayam banyak terkandung pencemaran mikroplastik, dibanding kawasan Pelabuhan Paotere.

2. Jumlah kelimpahan mikroplastik yang ditemukan perairan kota makassar yaitu di Pelabuhan Paotere

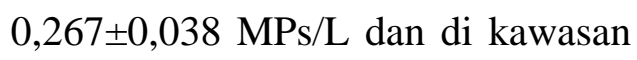
Pantai Tanjung Bayam dengan kelimpahan rata-rata $0,478 \pm 0,056$ MPs/L., dengan bentuk Fragment dan Line/Fiber. Warna yang terindetifikasi adalah warna putih, merah, transparan, hijau, biru, hitam dan cokelat. Ukuran mikroplastik yang ditemukan yaitu $>1 \mathrm{~mm}$ dan 1,00-4,75 $\mathrm{mm}$ dan $>4,75 \mathrm{~mm}$.

3. Keberadaan Pseudomonas pada perairan kota makassar, juga mempengaruhi proses degradasi dan sebagai bioremidiasi plastik menjadi mikroplastik.

4. Resiko toksisitas keberadaan yaitu mikroplastik dapat menjadi racun bagi organismedengan cara mentransfer senyawa kimia dari air ke organisme melalui pencernaan, mikroplastik dapat berada pada lambung dan akan terjadi reaksi adsorpsi yang didukung dengan luas permukaannya yang besar menyebabkan protein dan glikoprotein akan teradsorpsi ke permukaan partikel dan berdampak pada sistem imun dan terjadi inflamasi pada bagian pencernaan. 
Dari hasil penelitian yang telah dilakuan, maka dapat saya sarankan sebagai berikut.

1. Diperlukan regulasi untuk mengatur pengelolaan sampah plastik, dengan keterlibatan penegak hukum dan stake holder terkait untuk masyarakat agar tidak membuang sampah plastik pada aliran sungai, drainase maupun laut dikarenakan sumber terbesar pencemaran limbah plastik berasal dari limbah rumah tangga.

2. Diperlukan pembangunan sistem pengelolaan air limbah domestik terpusat (SPALD-T) dengan jaringan perpipaan yang terhubung ke setiap rumah.

3. Pada penelitian selanjutnya, perlu dilakukan penelitian kandungan mikroplastik dalam tubuh manusia.

4. Sebagai bahan rujukan untuk penelitian selanjutnya dalam menetapkan batas aman mikroplastik pada ekosistem akuatik serta Refrence Dose (RfD) mikroplastik terhadap manusia.

\section{UCAPAN TERIMA KASIH}

Ucapan terimakasih diberikan kepada pihak pengelola laboratorium Fakultas Kelautan dan Perikanan Universitas Hasanuddin sebagai tempat uji mikroplastik dalam penelitian ini dan kepada kakak Ir. Dewi Sartika Pasande, M.Sc yang membantu biaya pendidikan saya, lalu Bapak Dr. Muhammad Ikhtiar,SKM., M.Kes dan Bapak Dr. Alfina Baharuddin, S. KM., M.Kes selaku dosen pembimbing yang turut membantu dan mengoreksi dalam penulisan artikel ini, serta orang tua yang memberi dukungan dalam pembuatan artikel ini.

\section{DAFTAR PUSTAKA}

1. Rochman CM, Tahir A, Williams SL, Baxa D V., Lam R, Miller JT, et al. Anthropogenic debris in seafood: Plastic debris and fibers from textiles in fish and bivalves sold for human consumption. Sci Rep. 2015;5(August):1-10.

2. Widianarko B, Hantoro I. Mikroplastik Mikroplastik dalam Seafood Seafood dari Pantai Utara Jawa [Internet]. Unika Soegijapranata. Semarang. 2018. 86 halaman. Available from: cholar.google.es/scholar?hl=es\&as_s $\mathrm{dt}=0 \% 252 \mathrm{C} 5 \& \mathrm{q}=$ Funcionalidad $+\mathrm{Fa}$ miliar+en+Alumnos $+\mathrm{de}+1^{\circ}+\mathrm{y}+2^{\circ}+\mathrm{g}$ rado+de+secundaria+de+la+instituci ón+educativa+parroquial+"Pequeña +Belén"+en+la+comunidad+de+Per alvillo\%252C+ubicada+en+el+distri 
to+de+Chancay+-

+periodo+2018\&btn

3. Afdal M, Werorilangi S, Faizal A, Tahir A. Studies on Microplastics Morphology Characteristics in the Coastal Water of Makassar City, South Sulawesi, Indonesia. Int J Environ Agric Biotechnol. 2019;4(4):1028-33.

4. Kershaw Peter J. Marine plastic debris. Global lessons and research to inspire action. Unep. 2016;1-192.

5. GESAMP Joint Group of Experts on the Scientific Aspects of Marine Environmental Protection). Sources, fate and effects of microplastics in the marine environment: a global assessment (Kershaw, P. J., ed.). (IMO/FAO/UNESCO-

IOC/UNIDO/WMO/IAEA/UN/UNE

P/UNDP Joint Group of Experts on the Scientific Aspects of Marine Environmental Protection). Rep Stud GESAMP [Internet]. 2015;No. 90:96 p. Available from: www.imo.org

6. Lolodo D, Nugraha WA. Mikroplastik Pada Bulu Babi Dari Rataan Terumbu Pulau Gili Labak Sumenep. J Kelaut Indones J Mar Sci Technol. 2020;12(2):112-22.

7. Wicaksono EA, Tahir A, Werorilangi S. Preliminary study on microplastic pollution in surface- water at Tallo and Jeneberang Estuary, Makassar, Indonesia. AACL Bioflux. 2020;13(2):902-9.

8. Rahmadhani F. Identifikasi dan analisis kandungan mikroplastik pada ikan pelagis dan demersal serta sedimen dan air laut di perairan pulau mandangin kabupaten sampang. Skripsi. 2019;1-66.

9. Komunikasi $M$, Lingkungan $T$. Jurnal Presipitasi Perkembangan Penelitian Mikroplastik di Indonesia. 2020;17(3):344-52.

10. Singh B, Sharma N. Mechanistic implications of plastic degradation. Polym Degrad Stab. 2008 Mar 1;93:561-84.

11. Sriningsih A, Shovitri M. Potensi Iaolat Bakteri Pseudomonas Sebagai Pendegradasi Plastik. J Sains Dan Seni. 2015;4(2):67-70.

12. Islami AN. Biodegradasi Plastik Oleh Mikroorganisme. 2019;

13. Wright SL, Thompson RC, Galloway TS. The physical impacts of microplastics on marine organisms: a review. Environ Pollut [Internet]. 2013;178:483-92. Available from: http://dx.doi.org/10.1016/j.envpol.20 13.02.031

14. Hazimah N, Obbard J. Microplastics in Singapore's coastal mangrove 
ecosystems. Mar Pollut Bull. 2013 Dec 20;79.

15. Hafidh D, Restu IW, Made N. Kajian Kelimpahan Mikroplastik di Perairan Teluk Benoa Provinsi Bali. Curr Trends Aquat Sci [Internet]. 2018;88:80-8. Available from: http://snasppm.unirow.ac.id.id/eprosi ding6-pencemaran-mikroplastik-disepanjang-pantai-kabupatentuban.html

16. Karami A, Golieskardi A, Choo C,
Larat V, Galloway T, Salamatinia B. The presence of microplastics in commercial salts from different countries. Sci Rep. 2017 Apr 6;7.

17. Hollman PCH, Bouwmeester H, Peters R. Microplastics in aquatic food chain: sources, measurement, occurrence and potential health risks. 2013 Jan 1; 